\title{
ECUMENISM IN AFRICA AND THE FUTURE OF THE CONTINENT
}

Dionne Crafford

Centre for Contextual Hermeneutics

\begin{abstract}
This article interprets recent events in Africa from the point of view of ecumenism. Ecumenism is understood as closer co-operation between churches, but also between Christianity and social issues. Particular attention is given to the relationship of 'Africa' with the Dutch Reformed Church of South Africa. A mutual rapprochement is detected and supported.
\end{abstract}

Since the middle of the century many African countries were engaged in an independence struggle against colonial exploitation and aggression. In this stage the important word for most of Africa was 'liberation'. Liberation philosophies and liberation theology became very important. The decade of the sixties was the decade of uhuru for many countries which received independence. But in Southern Africa, the struggle for independence of Angola, Mozambique, Zimbabwe and Namibia continued. The cry for the liberation of Southern Africa was widely heard. At the same time the struggle for the liberation of blacks in South Africa from the dehumanizing structures of apartheid also continued. The motto was: Africa will not be free until blacks in South Africa are free. In the midst of a liberation struggle in the South, liberation theology flourished, while in the rest of Africa the emphasis was shifting towards an indiginization of the gospel in an African content.

Then followed the independence of Angola, Mozambique and also of Zimbabwe, after a period of struggle and of liberation wars. At last Namibia obtained independence and on 2 February 1990 president F W de Klerk launched a process of emancipation for South African blacks, and announced the unbanning of exiled liberation movements. Since then, all the apartheid laws have been revoked by Parliament, and a process of reform started which intends to establish a multi-racial South Africa in which all people will be free and participating citizens.

Since all these changes have taken place, new key words for Africa has come to the fore. No longer 'liberation', but 'reconciliation' and 'restoration' have become the important concepts. 
In South Africa there is a general desire for a new South Africa in which reconciliation could take place between fighting factions, divided tribes, opposing political parties and polarizing ideologies. There is a great need for restoration of peace, for restoration of human dignity and freedom, and for the restoration of nature and environment into a state of preservation, and not of exploitation.

It is, however, not only a new South Africa that is needed but also a new Africa. Great disillusionment was experienced in many African countries after independence. Coups d'etats, civil wars with enormous loss of lives and property, violence and unrest, corruption and a lack of individual freedom and freedom of the press, caused many people to despair in the future of Africa. In the economic field, things are even worse. African countries are hard hit by unequal trade relations, lack of technological and agricultural expertise, lack of trained manpower and entrepreneurs and by the debt crisis. The result is famine, poverty, collapse of basic social services, health and education institutions and the general infra-structures of many countries.

Against this background ecumenism is becoming tremendously important for the future of Africa. Churches are called to co-operate in the process of reconciliation and restoration. A united witness and united actions of the different churches in Africa are needed in order to contribute meaningfully towards peace, reconciliation and restoration. There was a time when the church in Africa was forced to participate in the liberation struggle. It was forced to take sides with specific liberation movements. Unfortunately this caused a lot of polarization and made ecumenical cooperation nearly impossible.

In the changed situation ecumenism becomes easier. Churches can now speak out in one voice against injustice, immorality and the exploitation of humanity and the environment. Now is the time to develop and strengthen ecumenical structures in Africa. I want to point out briefly the importance of four fields of ecumenism for the future of Africa: conciliar ecumenism, theological ecumenism, co-operative ecumenism and local ecumenism.

\section{Conciliar ecumenism}

The two important protestant ecumenical organizations of Africa are the All Africa Conference of Churches (AACC) and the Association of Evangelicals of Africa and Madagascar (AEAM) ${ }^{1}$.

The AACC first assembled in Kampala, Uganda in 1963, and comprises 139 member churches and associated councils in 38 African countries.

1. Crafford, D 1987. Mededelings oor moderne ekumeniese strominge in Africa, met spesiale verwysing na die AEAM en ACC, in Studia Historiae Ecclesiastica XIII, 1-15. Church History Society of Southern Africa.

Crafford, D 1988. Die ekumene in Afrika, in Uitdagings vir die Kerk in Afrika, UPTS, no 8, 94-113. Pretoria: NG-Kerkboekhandel. 
For a long time the liberation of Southern Africa was one of the priorities of the AACC. In its struggle against injustice, oppression and exploitation, it co-ordinated African churches' efforts to isolate South Africa politically and economically. It gave spiritual and financial support to liberation movements. It took a very critical stand against the Dutch Reformed Church in South Africa, because it was associated with the apartheid ideology in the country ${ }^{2}$.

The changes taking place in South Africa and the fact that the Dutch Reformed Church stated clearly its rejection of apartheid as a discriminatory ideology ${ }^{3}$, put a challenge before the AACC to reconsider its policy against South Africa and the Dutch Reformed Church.

On the ground of 'our pluralistic African-ness', as Nat Idarous of the AACC put it in his welcoming address at a dialogue between Afrikaner theologians and other African theologians in Narobi from 6-13 April 1991, there developed a consensus that black theologians from South Africa should explore ways of communication and co-operation. Afrikaners found their own identity as unquestionably belonging to Africa. But they can serve as bridge builders to Europe because of their European origin. This is being recognized more and more by statesmen and church leaders of Africa.

In his report on the conference between Afrikaner theologians and Black theologians in Nairobi, Prof Jean-Samuel Zoe-Obianga of Cameroon came to the conclusion:

We could no longer accept: white $=$ non African $=$ permanent representative of northern hemisphere domination of the South.

He then summarized the characteristics which constitute the common identity of the two groups as follows:

(a) Our frustration to have been colonised by foreign powers which totally disrespected our culture and the history of our roots.

(b) The Northern countries' rejection of us as full partners capable of being integrated without any form of discrimination into their so-called Universal Civilisation.

(c) Our awareness that initially we cannot afford to count on anyone other than ourselves in the framework of a history which we have made and which is making us what we are.

Prof Zoe-Obianga concluded his report:

This meeting represents a decisive step in the history of the Christian Church in Africa. The task remains now for us to exploit all these signs of hope which

2. For the Harare Declaration (1985) and the Lusaka Declaration (1987) on South Africa, see $P$

Rossouw, 1989. Ecumenical Panorama, 123, Pretoria.

3. Church and Society 1990. Statement of the DRC, General Synod, par 282-288. 
have issued from this encounter, in order that we shall see the aurora of the 'new Africa' which our Churches want to promote.

Indeed, the time has come for the AACC to put into practice its stated aim

... to encourage closer relationship and mutual sharing of experience among the Churches in Africa through visits, consultation and conference, and the circulation of information.

For the Dutch Reformed Church of South Africa, on the other hand, the time has come to prepare itself for full co-operation with the ecumenical movement of Africa. In order to reach this goal, a few conditions should be met by the church. A clear and final departure from the ideology and practice of apartheid should be visible to all. The doubt that some of our black colleagues have, that this has not been done sufficiently by the church, should be removed.

In the second place, the Dutch Reformed Church should normalize its relations with the predominantly black members of the Dutch Reformed Church family. Quarrels within a family is often more difficult to quench than those outside a family. The SACC and AACC can therefore play a positive role of reconciliation in this connection. A third condition is that the DRC should restore ecumenical ties with the South African Council of Churches.

It is very disappointing that the SACC at a recent meeting rejected the request of the DRC to become an observer member of the council. It shows that the council has not yet realized the importance of reconciliation for the future of a 'new South Africa', and the importance of an inclusive ecumenism for the future of a 'new Africa'. One can only hope that the DRC will not stop its efforts to become part of African ecumenism, and that the SACC will change its unforgiving attitude into a more reconciliatory spirit.

The AEAM was constituted in 1966 with only 8 Evangelical Fellowships. Today it comprises of 22 National Evangelical Fellowships, 32 Associate memberships and 19 special memberships. It represents about 50 million Christians in Africa.

Through a wide range of activities and development programmes, the AEAM is developing a holistic approach to the spiritual and material needs of Africa. In the process it is correcting its image as an organization which is not active enough in social and cultural involvement. It is also striving for a more relaxed relationship with the $A A C C$, and there are fields in which the two organizations plan to work together. An important sign of co-operation is that there is talk in the AEAM about jointly organizing a PACLA II leadership conference in Harare in 1993.

For the future of the church in Africa liaison and cooperation between the AACC and the AEAM is of the utmost importance. It should also be extended to Evangelical Fellowships and Christian Councils of the different countries.

It is possible and necessary that churches of the Reformed tradition with links with both organizations could play a liaisory role in the ecumenical polarization of Africa. It is therefore in the interest of the DRC of South Africa to consider at least Associate membership of the AEAM. The AEAM have already organized two con- 
sultations on South African Development, in which the racial issues of this country were discussed. The AEAM should continue on these lines and work towards a reconciliation of Christians in this country.

\section{Theological ecumenism}

For a long time theology in Africa focused primarily on liberation and contextualization. Black theology in South Africa formed an important part of this reflection.

The above mentioned changes that are taking place in Africa, call for a shift from contextualliberation theology to a contextual theology of inculturation. ${ }^{4}$ Where liberation theology tended to be ideological in the sense that it interpreted the gospel from the viewpoint of an ideology of liberation, inculturation theology has to do with the incarnation of the whole gospel in a specific socio-cultural environment. Where liberation theology moves from the context to the text and adapts the text in order to be relevant to the context, a theology of inculturation should move from the text to the context and allow the text to change the context in a relevant way.

Inculturation is the process of Christianizing a culture. It allows the gospel to take root in the thought patterns of non-Western peoples. It is a process through which the church and the principles of the Kingdom became part of a culture. It is when the Gospel begins to determine the life and world-view, and therefore the actions and attitudes of people. Inculturation does not mean the change of the Gospel to suit a specific culture, but the change and renewal of a culture according to the principles of the gospel. ${ }^{5}$

Since inculturation wants to apply the principles of the Kingdom in a cultural situation, it will also have to deal with matters of peace, justice and human rights in a specific situation.

In 1976 the Ecumenical Association of Third World Theologians (EATWOT) was established in Dar-es-Salaam in Tanzania. ${ }^{6}$ EATWOT wanted to emphasize the influence of political, social, economical, cultural and racial situations on practising theology. It wanted a theology of doing rather than one of confessing only. It chose for a preferential option for the poor and wanted to be the voice of the voiceless people in the society.

Because of the peculiar challenges for African Christianity, it was decided to establish an African section of EATWOT. In January 1990 the African office was opened in Harare, with Rev Emmanuel Kandusi as Africa Secretary.

4. Frei, Frits. Inculturation, in Collett G, (ed), Theologien der Dritten Welt. EATWOT als Herausforderung westlicher Theologie und Kirche. Neue Zeitschrift für Missionswissenschaft, Supplementa XXXVII, $162 f$.

5. Idem, 165.

6. Camps, A. Die Oekumenische Vereinigung von Dritte-Welt-Theologen (EATWOT), in Collett G, (ed), Theologien der Dritten Welt, $183 f$. 
EATWOT was actively involved in the liberation struggle of Southern Africa and its members participated in the formulation of documents like Kairos - and The Road to Damascus. Within EATWOT the emphasis will also have to shift from liberation to inculturation. All theologians living and working in Africa will have to struggle with the problem of the Africanisation of the Gospel and the creation of a genuine African theology.

In this effort theologians of the Dutch Reformed Church can play a role. They are well-trained in European theology, but forced to interpret it for the African situation. They can become useful partners in the theological debate in Africa.

What is needed is that EATWOT should become really ecumenical (as indicated in its name)and allow theologians of different persuasions and confessions to participate in the debate. Only in this way can a truly ecumenical theological debate take place and can theologians from different situations in Africa enrich each other.

\section{Co-operating ecumenism}

We have seen that the immense problems of Africa in the socio-economic and political fields force the Churches to work together in an effort of solving them.

The National Councils of Churches in different African countries serve as instruments of ecumenical co-operation. We can take one of the largest councils on the continent, the National Council of Churches in Kenia (NCCK), as an example. The NCCK was established in 1943 and has all the major Protestant Churches in Kenia as its members.

It co-ordinates co-operation between churches in seven different fields with a specific programme for each of them.

1. The Refugee Service Unit is a programme in which churches work together to relieve the suffering of the many refugees in the country.

2. The family life education programme. In it churches work together to educate families on matters such as malnutrition, child care, health, family planning, etc.

3. Urban community improvement programme. This programme concentrates on the poorest of the poor in urban, peri-urban and squatter settlements and organizes relief and self-help activities in order to improve the quality of life of suffering people.

4. The rural development programme, which concentrates on the neglected and underdeveloped rural areas. It speaks out for neglected groups and co-ordinates the development efforts of churches.

5. The Christian education and training programme. Through this programme churches are assisted in leadership training on a national and parish level. It provides lay training, youth leadership training, theological training and training for

7. In as much. National Council of Churches of Kenia (NCCK). A survey of life and work, NCCK, Nairobi, 1987. 
industrial mission and evangelism. For this purpose the Limuru Conference and Training Centre is operated under the auspices of the NCCK.

6. Christian communication. In this section the participation of churches in broadcasting on radio and television is co-ordinated, and audio-visual aids are provided for Churches.

7. The department for handicapped people.

This example shows that the church in Africa can play a very important role in social relief work if it is done in an ecumenical way.

In Kenia no less than $30 \%$ of all health and community development services are provided by the churches. Government and churches work closely together and joint committees are undertaking certain projects. In certain instances conflicts arise when the church exercises its prophetic calling and speaks out for the poor and against unjust legislation. Some Western donors lost faith in government institutions and prefer to channel their support through non-governmental organizations. The church has also become such an organization. The danger in such a situation is that the church may easily become an instrument for development and change, while neglecting its spiritual, religious and evangelizing functions. The challenge for the church is to exercise a holistic ministry of ecumenical nature in which the whole man in all his spiritual and physical needs will be attended to. The church must however realise that there are certain basic priorities in its ministry:

- to convert people and teach them

- to do the will of God

- to work for reconciliation between man and God and between individuals and groups

- to work for the implementation of the Kingdom principles in society

- to create respect for the human being and to support basic human rights

- to promote Christian values of truth, justice, honesty, faithfulness, diligence, etc.

The SACC can learn much from the example of the NCCK. For a long time the SACC was seen as an instrument in the struggle for liberation. This function can now be transferred to the different political parties. The SACC must reconsider its priorities and return to its basic ecumenical function as council of churches. It is high time for churches in South Africa to solve their mutual ideological and confessional differences, and start with cooperative ecumenism in order to help with the reconstruction of not only a new South Africa, but also a new Africa.

The Dutch Reformed Church of South Africa - with its spiritual and material resources - must not refuse to be part of this ecumenical process. 


\section{Local ecumenism}

Far too long ecumenism was practised on the leadership level of churches in Africa and elsewhere in the world. On parish level very few people even know the meaning of the word ecumenism. What is necessary is that churches should learn to cooperate on the local level. Evangelism, mission, relief work, community development, witness to authorities etc, can best be done jointly in a local situation between churches that face a common challenge. If the church really wants to make its influence felt in a future Africa, it will have to develop a local ecumenism. Only then will the world really see and believe that God has sent His son as saviour into this sinful and suffering world.

\section{BIBLIOGRAPHY}

Camps, A. Die Oekumenische Vereinigung von Dritte-Welt-Theologen (EATWOT), in Collett (ed), Theologien der Dritten Welt. Neue Zeitschrift für Missionswissenschaft, Supplementa XXXVII.

Church and Society 1990. Statement of the DRC, General Synod.

Crafford, D. Mededelings oor moderne ekumeniese strominge in Afrika met spesiale verwysing na die AEAM en ACC, in Studia Historiae Ecclesiastica XIII, 1987.

Church History Society of Southern Africa.

Crafford, D. Die Ekumene in Afrika, in Uitdagings vir die Kerk in Afrika, UPTS No 8. NG-Kerkboekhandel 1988, Pretoria, 1990.

Frei, Frits. Inkulturation, in Collett G, (ed), Theologien der Dritten Welt. EATWOT als Herausforderung westlicher Theologie und Kirche. Neue Zeitschrift für Missionswissenschaft, Supplementa XXXVII.

In as much. National Council of Churches of Kenia (NCCK). A survey of life and work, NCCK, Nairobi, 1987.

Rossouw, P. Ecumenical Panorama. Pretoria 1989. 